\title{
No size or density effect on alternative mate-locating tactics in the tropical damselfly Hetaerina rosea males (Odonata: Calopterygidae)
}

\author{
Paulo Enrique C. Peixoto ${ }^{1}$ \& Paulo De Marco Jr. ${ }^{2}$ \\ 1. Departamento de Zoologia, IB, UNICAMP, C.P.6109, CEP 13083-970, Campinas, São Paulo, Brasil; \\ popscardoso@yahoo.com.br \\ 2. Departamento de Biologia Geral, Universidade Federal de Goiás, Goiânia, Brasil; pdemarco@icb.ufg.br
}

\author{
Received 06-V-2008. C Corrected 12-VII-2008. Accepted 18-VIII-2008.
}

\begin{abstract}
Males of the damselfly Hetaerina rosea may defend mating sites along river margins (resident males) or, alternatively, wander among different areas presumably searching for mates (nonterritorial males). Although the occurrence of territorial and nonterritorial males of $H$. rosea is very common in Brazil, studies examining which factors may be responsible for the adoption of alternative mate-locating tactics in this species are inexistent. We investigated the relationship between the adoption of these alternative mate-locating tactics by males of H. rosea and two possible causes: body weight and male abundance. We carried the study in three areas: sites 1 , 2 and 3. Samples were monthly undertaken in sites 1 and 2 between September/2001 and August/2002 and in site 3 between May/1999 and January/2001. Using the scan method with fixed areas and mark-resighting techniques, we did not find any relationship between the proportion of nonterritorial males and male abundance per month on sites $2(n=6)$ and $3(n=7)$, indicating that the adoption of alternative mate-locating tactics is not affected by competition for territories. In the same way, nonterritorial and resident males showed similar body and thoracic weight measures ( $\mathrm{n}=30$ and $\mathrm{n}=27$ for sites 2 and 3 respectively). Maybe the nonterritorial tactic is adopted by individuals searching for better territories or males that were evicted from their defended sites. The absence of relationship between weight and male territorial status is in accordance with other Hetaerina species. However, other traits not investigated here such as parasitic load, fat content and age may influence the adoption of different mate-acquisition tactics in H. rosea males. Rev. Biol. Trop. 57 (1-2): 361-370. Epub 2009 June 30.
\end{abstract}

Key words: alternative mate-locating tactics, mating systems, territoriality, resource holding potential, density, Hetaerina rosea, Calopterygidae.

The occurrence of mating systems with territorial defence is widespread among insects (Thornhill and Alcock 1983). In these systems, territorial males often increase their mating success by locating themselves in areas with high probability to encounter females (Córdoba-Aguilar and Cordero-Rivera 2005). However, the number of males able to establish and defend a territory is frequently many times higher than the availability of suitable sites for territorial defence (Alcock and O'Neill 1987, Forsyth and Montgomerie 1987, Lefevre and Muehter 2004). Consequently, males have two options: experience great costs in fighting for the possession of high quality areas that pro- vide higher mating success or adopt alternative (less costly and profitable) nonterritorial tactics to seek for mates. However, in many insect species it is not clear which factors drive males to adopt either the territorial or nonterritorial tactics (Alcock et al. 1978, Kemp and Wiklund 2001, Córdoba-Aguilar and Cordero-Rivera 2005).

In some insect species, the occurrence of different mate-locating strategies is clearly associated with morphological traits, such as the presence of horns in the beetle Onthophagus acuminatus (Emlen 1997) and wing colours dimorphism in the damselfly Mnais pruinosa costalis (Watanabe 1990). In these species, the 
adoption of different mating tactics is often restricted by male morphology and none or a few males are able to switch among alternative mate-locating strategies. On the other hand, there are species which posses less clear differences among males with distinct mate-locating behaviours (Forsyth and Montgomerie 1987, Alcock 1994, Plaistow 1997). In these situations, males generally compete for the possession of territories and individuals that loose this competition are forced to adopt less profitable behaviours in terms of the expected number of matings.

When competing for the possession of territories, males with higher fighting capacity (RHP - resource holding potential) are expected to have an advantage to win disputes (Maynard Smith and Parker 1976, Enquist and Leimar 1983, Haccou and Glaizot 2002). Among insects, weight and size are two of the most frequently characteristics related to the adoption of different male mate-locating tactics (Alcock et al. 1978, Kemp and Wiklund 2001, Córdoba-Aguilar and Cordero-Rivera 2005). However, a great puzzle is to functionally link these traits to their role in resolving disputes. For example, if coercion is important to decide the winner of a dispute, weight and size should confer a direct advantage in subduing rivals and consequently may be directly related to RHP. Alternatively, in species that rely on physiological conditions to settle disputes, weight and size should be associated with RHP only if greater males possess higher muscle mass, are able to store more energy reserves or sustain less parasitic load (Córdoba-Aguilar and Cordero-Rivera 2005, Serrano-Menezes et al. 2007).

If the nonterritorial tactics are adopted as less profitable alternatives by weaker males when there is intense competition for the available mating areas, the proportion of nonterritorial males should be a direct function of the number of individuals competing for the available sites (Alcock and O'Neill 1986, Cordero 1999). Also, morphological or physiological differences among males with distinct matelocating tactics should be stronger when the competition is more intense. In this sense, if the territorial defence provides higher mating success, all individuals should adopt this tactic during periods of low male abundance when there must be a high availability of suitable sites to territorial defence per male. However, at higher male densities, the availability of defensible areas may limit the number of territorial males and lead to the appearance of nonterritorial individuals (Forsyth and Montgomerie 1987, Cordero 1999).

Among odonates, and especially in the family Calopterygidae, the occurrence of mating systems with territorial defence and the presence of nonterritorial males is very common (Córdoba-Aguilar and Cordero-Rivera 2005). Nevertheless, detailed behavioural studies are concentrated on temperate species and poorly are known about the tropical ones. Temperate and tropical species are subject to different climatic regimes that may confer different selective pressures. Consequently, the study of tropical species can potentially add balance to the general picture of selective forces that shape reproductive systems in this group of insects.

Hetaerina rosea (Selys 1873) is a tropical damselfly species predominantly found on streams and is especially abundant in degraded rivers of Viçosa, MG, Brazil (Peruquetti and De Marco 2002, De Marco and Peixoto 2004). Males of this species show two main behaviours of mate acquisition: some individuals are repeatedly found defending a specific point in the stream margins (resident males), while others move continuously between territories without establishing on any specific site (nonterritorial males - Peixoto and De Marco, unpublished data). To our knowledge, there are no previous behavioural studies on $H$. rosea and attempts to clarify the causes related to differences between nonterritorial and resident males are nonexistent.

Here we attempted to describe some basic aspects of male mating behaviours in $H$. rosea and to investigate the influence of body weight and male abundance on the adoption of different mate-locating tactics by males. Specifically, 
we expect that, if the number of territories is fixed and the territorial defence increases male mating success, the proportion of nonterritorial males will be higher during periods of high male abundance. Additionally, if greater weight is associated with higher RHP, heavier males are expected to adopt the territorial tactic while lighter males will be forced to adopt the nonterritorial alternative.

\section{MATERIALS AND METHODS}

Study area: We performed this work on São Bartolomeu stream, a river with one to three meters width that crosses a small urban area at Viçosa, MG, Brazil. The region has a $\mathrm{CWb}$ climate in Köppen classification, showing a decline in soil water content between May and September and excess between December and March (Golfari 1975). The mean annual precipitation is $1450 \mathrm{~mm}$, relative air moisture around $80 \%$ and mean annual temperature ranging from $14{ }^{\circ} \mathrm{C}$ to $26.1{ }^{\circ} \mathrm{C}$ (Valverde 1958).

We selected three study sites (sites 1,2 and 3 ) to collect the field data. On site 1, the stream cross a pasture area and is surrounded by a strip of bushes, receiving only a few sewer discharge and some domestic animal faeces that feed nearby. During the raining season, the river flow velocity was greatest among the three sites (January $/ 2002$; mean velocity $=0.596 \mathrm{~m} / \mathrm{s}$; $\mathrm{sd}=0.292$ ). Site 2 is closer to site 1 (approximately $50 \mathrm{~m}$ ) than to site 3 (approximately 500 $\mathrm{m})$. The sewer discharge in this area is similar to site 1 , but the river flow measured during the raining season is similar to site 3 (mean velocity $=0.261 \mathrm{~m} / \mathrm{s}, \mathrm{sd}=0.147$ ). In this area there are sections of still water, which were excluded from our analyses. There are trees concentrated at the beginning of this site and some shrubs ( $>1 \mathrm{~m}$ height) dispersed along the margins. Finally, site 3 is adjacent to a major urban concentration and therefore is exposed to a more intense domestic sewer discharge. This is a pasture area and presents some trees dispersed along the margins. The mean river flow is similar to site 2 , but without still water areas (mean velocity $=0.260 \mathrm{~m} / \mathrm{s}$; $\mathrm{sd}=0.115$ ).
General observations on Hetaerina rosea: We estimated the monthly male and female abundance using the scan method with fixed areas (Peruquetti and De Marco 2002). We took 50 consecutive segments of two meters on sites 1 and 2 , and 49 consecutive segments on site 3. During the scan, we walked through the area and counted the number of individuals present in each segment for at least three different days per month. We did all scans between 10:00 and 14:00 $\mathrm{h}$ and, in order to avoid repeated counts of the same individuals, never spent more than two minutes inspecting the same segment.

After each scan, we captured all nonmarked males and females present in the area with an entomological net and, using a water resistant black pen, marked each adult with a unique number combination on the forewings. After marking, the individuals were released at the same point where they were captured. This procedure allowed the resighting and identification of adults on subsequent days without recapture. Whenever we resighted a marked male, we recorded if it was defending the segment where it was located.

Previous analysis revealed that $55 \%$ of the 104 males resighted for at least five days (pooled across all study sites) were always defending territories located in a range of one to four consecutive segments. These males frequently inspected other insects or conspecifics males that passed nearby (sometimes engaging in territorial disputes), and returned afterward to his previously defended area. The other $45 \%$ comprehended males that changed their locations between five and 41 segments on different days. Hence, we assigned a marked male to be resident when it defended a maximum of four consecutive segments and nonterritorial when it was seen between five or more segments (not necessarily consecutive) on different days. We compared the frequency of resident and nonterritorial males among sites using a Chi-square test (Snedecor and Cochran 1980).

We took samples in sites 1 and 2 between September/2001 and August/2002 and in site 3 between May/1999 and January/2001. We did 
65 scans and marked 172 males in site 1, 57 scans and 181 marked males in site 2 and 96 scans and 518 marked males in site 3 .

Density hypothesis: To determine if the number of males with alternative mate-locating tactics is related to male density, we compared the ratio of nonterritorial to resident males with the mean male abundance per month using spearman rank correlation (Snedecor and Cochran 1980). To calculate the mean male abundance on each month, we used the mean number of males per segment in each scan as the sample unity. If a male was resighted on more then one month, we classified its tactic using the data obtained during the month that encompassed more than $60 \%$ of its resightings (males that could not be assigned in this way were excluded from analyses).

To verify whether male density influence the time spent in territorial defence, we measured the proportion of time spent by males located on segments that showed different patterns of occupation. Our assumption is that high-quality segments (areas that may provide greater encounter rates with females) must have greater male densities. Consequently, males defending these areas may spend more time in territorial defence than males located at low-quality segments due to the greater number of individuals trying to take-over the better territories. To test this hypothesis we analyzed the relationship between the proportion of time spent in territorial disputes (time spent in the territorial dispute divided by total observation time) and male density using Spearman rank correlation (Snedecor e Cochran 1980). To calculate the proportion of time spent in territorial disputes, we observed and timed the behaviours of randomly chosen males for 60 seconds between 10:00 and 14:00 h (we considered each behavioural sequence as the sample unity). To estimate the quality of each territory, we calculated the mean male number observed inside each segment averaged per scan over the study period.

Weight hypothesis: After resighting a male for at least five days (not necessarily consecutive), we assigned a mate-locating tactic (resident or nonterritorial - see above) and captured it in order to measure its total and thoracic weight. To take these measures we placed all males in a drying oven at $60^{\circ} \mathrm{C}$ for at least 96 hours and next weighted each individual in an analytical balance with precision of $0.001 \mathrm{~g}$ (thoraxes were weighted without wings). We compared the number of males adopting each mate-locating tactic with their body and thoracic weight using Multiple logistic regression (Hosmer and Lemeshow 1989).

\section{RESULTS}

\section{General observations on Hetaerina rosea:}

Using the number of males and females counted during the scans, we estimated the sexual ratio to be 0.018 females/males on site $1,0.028$ females/males on site 2 and 0.058 females/ males on site 3 . We saw three copulations and in all observations the mating pair left the territory in tandem and, after landing in an area to oviposit, the female submerged completely. After female submersion, the male adopted a non-contact guarding behaviour in the area. We never saw the female re-emergence.

Territorial disputes among $H$. rosea males were characterized by a series of spiral flights and chases between rivals near the territory defended by the resident male. There were no differences in the number of resident and nonterritorial males among sites $\left(\chi^{2}=3.797, \mathrm{df}=2\right.$, $\mathrm{p}=0.150)$. The proportion of nonterritorial to resident males was $1(\mathrm{n}=8), 0.66(\mathrm{n}=40)$ and $1.52(\mathrm{n}=53)$ in sites 1,2 and 3 respectively.

The maximum abundance on a month was 0.42 males/segment on site $1,0.33$ on site 2 and 1.15 on site 3 . All study sites showed a decline in male abundance between July and September (Fig. 1). On sites 1 and 2 the mean male abundance was nearly stable during the raining season, showing a small decline during the dry season. The variation of male abundance was stronger on site 3 , showing a sharp increase during raining season followed by an accentuated decline during May and June. 



Fig. 1. Mean monthly male abundance per segment in site 1 (A), site 2 (B) and site 3 (C). Bars represent the standard error. Fig. 1C was adapted from Peixoto \& De Marco 2004.

Density hypothesis: The number of resightings on site 1 was very low to allow statistical analyses. Consequently, unless stated, we did not use data from site 1 in the following results.
On sites 2 and 3 the proportion of nonterritorial males did not change with male density throughout the year (Spearman correlation: $\mathrm{R}_{\mathrm{s}(\text { site })}=-0.486 ; \mathrm{n}=6, \mathrm{p}=0.329 ; \mathrm{R}_{\mathrm{s}(\text { site } 3)}=-0.185$, $\mathrm{n}=7, \mathrm{p}=0.443$; Fig. 2 ), suggesting that the adoption of alternative mate-locating tactics is not affected by competition for territories.

We did a total of 73 behavioural observations of marked males (summed across the three sites). In general, they remained perched the great majority of time (mean $=96.7 \%$, se $=0.1$ ), and spent just $1.3 \%$ ( $\mathrm{se}=0.7$ ) of their time budget in territorial defence against rivals (samples pooled across all areas).

Since disputes among males for the possession of territorial sites was rarely seen during the standardized observations, we pooled data from the three sites to perform statistical analyzes. The mean male density inside each territory did not influence the proportion of time spent in territorial interactions (Spearman correlation: $\mathrm{R}_{\mathrm{s}}=-0.09 ; \mathrm{n}=73, \mathrm{p}=0.454$; Fig. 3 ), suggesting that greater male density do not cause increases in the costs related to territorial defence.

Weight hypothesis: Resident and nonterritorial males presented very similar thoracic and body weight measures (Table 1). There was no difference in total or thoracic weight between males with different mate-locating tactics in both sites (Multiple logistic regression: $\chi^{2}=3.016, \mathrm{df}=2, \mathrm{p}=0.221, \chi^{2}=1.287$, $\mathrm{df}=2, \mathrm{p}=0.525$; sites 2 and 3 respectively).

\section{DISCUSSION}

The behaviours observed in $H$. rosea were very similar to those described for other Heaterina species (Córdoba-Aguilar and Cordero-Rivera 2005). Resident males tended to return to the same territory on different days and after disputes with conspecific rivals. Males defended territories near river margins with no evident resources and competed for the possession of these areas via aerial circular flights. However, resident males located at sites with higher male abundance did not spent more 


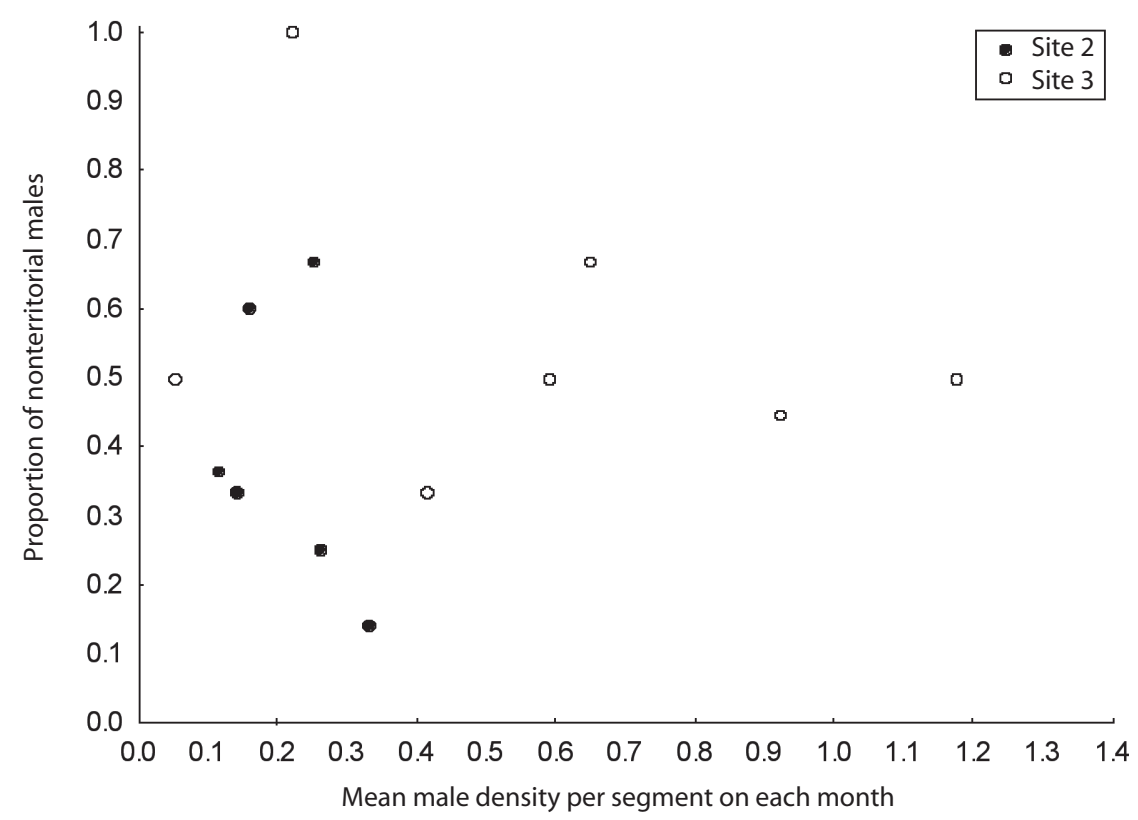

Fig. 2. Proportion of nonterritorial males in relation to the mean male density per segment averaged per month.



Fig. 3. Proportion of time spent in territorial disputes of the focal male against conspecific rivals in relation to the mean male density inside the segment. 
TABLE 1

Mean body and thoracic weights of resident and nonterritorial males captured on sites 2 and 3

(SD indicate the standard deviation)

\begin{tabular}{|c|c|c|c|c|c|}
\hline Site & Tactic & Measure & Mean weight (mg) & SD & Sample size \\
\hline 2 & Resident & body & 17.6 & 2.0 & 17 \\
\hline 2 & Nonterritorial & body & 17.1 & 2.1 & 13 \\
\hline 2 & Resident & thorax & 9.1 & 1.2 & 17 \\
\hline 2 & Nonterritorial & thorax & 9.1 & 1.3 & 13 \\
\hline 3 & Resident & body & 19.0 & 2.7 & 15 \\
\hline 3 & Nonterritorial & body & 18.2 & 1.7 & 12 \\
\hline 3 & Resident & thorax & 9.7 & 2.1 & 15 \\
\hline 3 & Nonterritorial & thorax & 9.0 & 1.1 & 12 \\
\hline
\end{tabular}

time in territorial defense. Although sometimes engaging in territorial disputes, nonterritorial males did not show weight differences from residents and did not increase in relative abundance during periods of high male density.

Theory regarding mating systems suggests that males should increase their reproductive success by defending mating territories under a combination of several conditions such as high male/female ratio, low population density and predictable distribution of defendable resources in space and time (Emlen and Oring 1977, Conrad and Pritchard 1992). The populations of $H$. rosea investigated here showed a strongly male biased sexual ratio and, as expected under the sexual ratio hypothesis, territoriality was common. On the other hand, density variations inside each site and the abundance differences among them did not influence changes in the proportion of nonterritorial males.

Which mechanisms could explain the absence of the relationship between the proportion of nonterritorial males and male abundance? If suitable sites for territorial defence are scarce, the proportion of nonterritorial males should have increased in places of high abundance, especially on site 3 . In this sense, one possibility is that the territories suitable to territorial defence are not a limiting factor. However, if this is true, the presence of nonterritorial males becomes a puzzle. Perhaps they are represented by individuals searching for better territories, possibly very young or older males (Plaistow 1997). However, since females submerge to oviposit outside the male territory, it is difficult to assess how males could evaluate the quality of the defended site (Córdoba-Aguilar and Cordero-Rivera 2005). In some odonate species, males evaluate the quality of each site based on the number of encounters with females (Switzer 1997) or river flow velocity (Gibbons and Pain 1992). If this occurs in $H$. rosea, nonterritorial males could be represented by individuals that, after experiencing a low encounter rate with sexual partners on their previous defended area, started to look for more suitable sites.

The occurrence of alternative mate-locating tactics is very common among species of the family Calopterygidae (Córdoba-Aguilar and Cordero-Rivera 2005). Some studies have shown that the resident tactic confers a greater mating success than the satellite or wanderer tactics (Grether 1996, Plaistow and Siva-Jothy 1996, Serrano-Menezes et al. 2007), and in some species, there is evidence of RHP asymmetries between resident and satellite males (Marden and Waage 1990, Marden and Rollins 1994). However, evidences of morphological differences are scarce. Size and weight are also weakly or not correlated with territorial success in the few studied Hetaerina species (Lefevre and Muehter 2004, Córdoba-Aguilar and Cordero-Rivera 2005). An exception 
comes from the study of Serrano-Menezes et al. (2007) on H. americana, which suggested that, although sizes differences were not found between nonterritorial and territorial males, there was a positive relationship between body size and territory tenure.

On the other hand, there is increasing evidence of physiological differences among males with different mate-locating tactics in Calopterygidae species. In general, resident males tend to differ from nonterritorial individuals in characteristics such immune response (Marden and Cobb 2004, Contreras-Garduño et al. 2007), fat content (Marden and Waage 1990, Marden and Rollins 1994) or age (Forsyth and Montgomerie 1987, Plaistow 1997). In Hetaerina americana, a series of experiments have demonstrated that the red basal spot on the male wings may function as an honest signal of health that could be used as a cue for mutual evaluation during territorial disputes (Grether 1996, Contreras-Graduño et al. 2006). Our results corroborate the possibility that the traits important to the adoption of different male tactics in $H$. rosea do not dependent on male weight and indirect relationships between weight and physiological conditions are inexistent. However, it remains to be investigated the immunological pathways associated with male RHP and also the relative influence of other potential traits such as energy reserves and age on the adoption of different mate-locating tactics. In especial, it is necessary to investigate the way males use these informations during the disputes and which factors are responsible for the presence of nonterritorial individuals. Will males adopt non-contact stereotyped fighting and use visual cues to decide the winner of a contest? Are males able to evaluate the quality of territories? The female distribution affects the selection of territories by males?

\section{ACKNOWLEDGMENTS}

We thank Alessandra Pereira Majer and Gustavo Requena for their helpful comments on the manuscript and Marcus Vínícius C. Vital for his help in fieldwork and many fruitful discussions. We also thank to the colleagues at the Laboratório de Ecologia Quantitativa (UFV) that supported in many different aspects of this work and Ipema for the support during the data collection. This work was partially founded by Conselho Nacional de Desenvolvimento Científico e Tecnológico (CNPq).

\section{RESUMEN}

Los machos de la libélula Hetaerina rosea pueden defender sus sitios de apareamiento a lo largo de márgenes de ríos (machos residentes) o, alternativamente, deambulan entre diferentes áreas presumiblemente buscando pareja (machos no territoriales). Aunque la existencia de machos territoriales y no territoriales de $H$. rosea es muy común en Brasil, no hay estudios que examinen cuáles factores pueden ser responsables para la adopción de tácticas alternativas para localizar pareja en esta especie. Investigamos la relación entre la adopción de estas tácticas alternativas para localizar pareja por machos de H. rosea, y dos posibles causas: peso del cuerpo y abundancia de machos. Realizamos el estudio en tres áreas: sitios 1, 2 y 3. Las muestras se tomaron mensualmente en sitios 1 y 2 entre setiembre 2001 y agosto 2002, y en sitio 3 entre mayo 1999 y enero 2001. La adopción de tácticas alternativas de localización de machos no se ve afectada por competencia por territorios. La ausencia de relación entre peso y estatus del macho territorial coincide con otras especies de Hetaerina. No obstante, otros rasgos que no fueron estudiados aquí, como la carga de parásitos, contenido de grasa y edad, pueden influenciar la adopción de diferentes tácticas de adquisición de pareja en machos de $H$. rosea.

Palabras clave: tácticas alternativas de localización de pareja, sistemas de apareamiento, territorialidad, potencial de contenido de recursos, densidad, Hetaerina rosea, Calopterygidae.

\section{REFERENCES}

Alcock, J. 1994. Alternative mate-locating tactics in Chlosyne californica (Lepidoptera, Nymphalidae). Ethology 97: 103-118.

Alcock, J., E.M. Barrows, G. Gordh, L.J. Hubbard, L. Kirkendall, D.W. Pyle, T.L. Ponder \& F.G. Zalom. 1978. The ecology and evolution of male reproductive behaviour in the bees and wasps. Zool. J. Linn. Soc. 64: 293-326.

Alcock, J. \& K.M. O’Neill. 1986. Density-dependent mating tactics in the gray hairstreak, Strymon melinus (Lepidoptera, Lycaenidae). J. Zool. 209: 105-113. 
Alcock, J. \& K.M. O’Neill. 1987. Territory preferences and intensity of competition in the gray hairstreak Strymon melinus (Lepidoptera, Lycaenidae) and the tarantula hawk wasp Hemipepsis ustulata (Hymenoptera, Pompilidae). Am. Mid. Nat. 118: 128-138.

Conrad, K.F. \& G. Pritchard. 1992. An ecological classification of odonate mating systems: the relative influence of natural, inter- and intra-sexual selection on males. Biol. J. Linn. Soc. 45: 255-269.

Contreras-Garduño, J., J. Canales-Lazcano \& A. CórdobaAguilar. 2006. Wing pigmentation, immune ability, fat reserves and territorial status in males of the rubyspot damselfly, Hetaerina americana. J. Ethol. 24: $165-173$.

Contreras-Garduño, J., H. Lanz-Mendoza \& A. CórdobaAguilar. 2007. The expression of a sexually selected trait correlates with different immune defense components and survival in males of the American rubyspot. J. Ins. Physiol. 53: 612-621.

Cordero, A. 1999. Forced copulations and female contact guarding at a high male density in a calopterygid damselfly. J. Ins. Behav. 12: 27-37.

Córdoba-Aguilar, A. \& A. Cordero-Rivera. 2005. Evolution and ecology of Calopterygidae (Zygoptera: Odonata): status of knowledge and research perspectives. Neotrop. Entomol. 34: 861-879.

De Marco, P.Jr. \& P.E.C. Peixoto. 2004. Population dynamics of Hetaerina rosea Selys and its relationship to abiotic conditions (Zygoptera: Calopetrygidae). Odonatologica 33: 73-81.

Emlen, D.J. 1997. Alternative reproductive tactics and male-dimorphism in the horned beetle Onthophagus acuminatus (Coleoptera: Sacrabaeidae). Behav. Ecol. Sociobiol. 41: 335-341.

Emlen, S.T. \& L.W. Oring. 1977. Ecology, sexual selection, and the evolution of mating systems. Science 197: 215-223.

Enquist, M. \& O. Leimar. 1983. Evolution of fighting behavior - decision rules and assessment of relative strength. J. Theor. Biol. 102: 387-410.

Forsyth, A. \& R.D. Montgomerie. 1987. Alternative reproductive tactics in the territorial damselfly Calopteryx maculata: sneaking by older males. Behav. Ecol. Sociobiol. 21: 73-81.
Gibbons, D.W. \& D. Pain. 1992. The influence of river flow rate on the breeding behaviour of Calopteryx damselflies. J. Anim. Ecol. 61: 283-289.

Golfari, L. 1975. Zoneamento Ecológico do Estado de Minas para Reflorestamento. CPRFC, Belo Horizonte, Minas Gerais, Brazil.

Grether, G.F. 1996. Intrasexual competition alone favors a sexually dimorphic ornament in the rubyspot damselfly Hetaerina americana. Evolution 50: 1949-1957.

Haccou, P. \& O. Glaizot. 2002. The ESS in an asymmetric generalized war of attrition with mistakes in role perception. J. Theor. Biol. 214: 329-349.

Hosmer, D. W. \& S. Lemeshow. 1989. Applied Logistic Regression. Wiley, New York, New York, USA.

Kemp, D.J. \& C. Wiklund. 2001. Fighting without weaponry: a review of male-male contest competition in butterflies. Behav. Ecol. Sociobiol. 49: 429-442.

Lefevre, K.L. \& V.R. Muehter. 2004. Competition for mating resources in a territorial damselfly (Odonata: Calopterygidae). Stud. Neotrop. Faun. Envi. 39: 159-165.

Marden, J.H. \& J.K. Waage. 1990. Escalated damselfly territorial contests are energetic wars of attrition. Anim. Behav. 39: 954-959.

Marden, J.H. \& R.A. Rollins. 1994. Assessment of energy reserves by damselflies engaged in aerial contests for mating territories. Anim. Behav. 48: 1023-1030.

Marden, J.H. \& J.R. Cobb. 2004. Territorial and mating success of dragonflies that vary in muscle power output and presence of gregarine gut parasites. Anim. Behav. 68: 857-865.

Maynard Smith, J. \& G.A. Parker. 1976. The logic of asymmetric contests. Anim. Behav. 24: 159-175.

Peruquetti, P.F. \& P. De Marco, Jr. 2002. Efeito da alteração ambiental sobre comunidades de Odonata em riachos de Mata Atlântica de Minas Gerais, Brasil. Rev. Bras. Zool. 19: 317-327.

Plaistow, S.J. 1997. Variation in non-territorial behaviour in male Calopteryx esplendens xanthostoma (Charpentier) (Zygoptera: Calopterygidae). Odonatologica 26: 171-181. 
Plaistow, S.J. \& M.T. Siva-Jothy. 1996. Energetic constraints and male mate-securing tactics in the damselfly Calopterix splendens xathosthoma (Charpentier). Proc. R. Soc. Lond. B 263: 1233-1239.

Serrano-Menezes, M.A., A. Córdoba-Aguilar, V. Méndez, S.J. Layen \& T. Székely. 2007. Sexual size dimorphism in the American rubyspot: male body size predicts male competition and mating success. Anim. Behav. 73: 987-997.

Snedecor, G. W. \& W. G. Cochran. 1980. Statistical Methods. Iowa State Universityu, Ames, Iowa, USA.
Switzer, P.V. 1997. Factors affecting site fidelity in a territorial animal, Perythemis tenera. Anim. Behav. 53: 865-877.

Thornhill, R. \& J. Alcock. 1983. The Evolution of Insect Mating Systems. Harvard University, Cambridge, United Kingdom.

Valverde, O. 1958. Estudo regional da Zona da Mata de Minas Gerais. Rev. Bras. Geo. 20: 3-79.

Watanabe, M. 1990. Mating tactics and male wing dimorphism in the damselfly, Mnais pruinosa costalis Selys (Odonata: Calopterygidae). J. Ethol. 8: 129-137. 